\title{
PREDICTORS OF BONE MINERAL DENSITY IN ADOLESCENTS WITH EXCESS WEIGHT
}

\author{
PREDITORES DA DENSIDADEMINERAL ÓSSEA EM ADOLESCENTES COM EXCESSO DE PESO
}

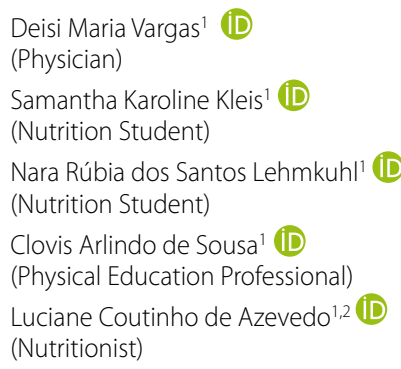

1. Fundação Universidade Regional de Blumenau (FURB), Blumenau, SC, Brazil.

2. Universidade do Vale do Itajaí (UNIVALI), Itajaí, SC, Brazil.

\section{Correspondence:}

Luciane Coutinho de Azevedo Rua São Paulo, 3250, Itoupava Seca. CEP: 89030-000, Blumenau, SC, Brazil. lu.cda@hotmail.com

\begin{abstract}
Introduction: Adolescence is characterized as a phase of intense development of the skeletal system. Maximizing bone mass acquisition during adolescence may reduce the risk of bone fractures later in life. Objectives: To analyze bone mineral density (BMD) and its relation to nutritional status and serum vitamin $D$ in adolescents with excess weight. Methods: This is a cross-sectional, exploratory study. Data from 102 adolescents with excess weight, of both sexes, were analyzed. The following indices were evaluated: body mass index (BMI), abdominal circumference (AC), intake of micronutrients (vitamin D, calcium, magnesium and phosphorus), serum 25-hydroxycholecalciferol $(25(\mathrm{OH}) \mathrm{D}$ concentration, BMD of the proximal femur, lumbar spine (L1-L4) and total body, \% body fat mass (\% BFM), total BFM, total body lean mass (BLM), body fat mass (BFMI) and lean mass (BLMI). Results: The male adolescents $(n=53)$ had higher values for weight, height, $A C, B L M$ and BLMI, while the females $(n=49)$ had higher \% BFM. The majority were obese $(53.9 \%)$ and had a BMD within the normal range for all evaluation sites. Of the 84 adolescents ( $n=84$ ) with laboratory examination of $25 \mathrm{OHD}, 33.3 \%$ presented values considered insufficient or deficient. Multivariate linear regression analysis showed that the most important independent predictor of BMD for the girls was BLMI, regardless the evaluation site. For boys, in addition to BLMI, BMI-Z of the proximal femur (neck of the femur and total) was also was a determinant variable for BMD. Conclusion: In this sample of adolescents, BLMI was a positive predictor of BMD in both sexes; and BMI-Z was a positive predictor only in proximal femur in the boys. Level of evidence Il; Prognostic studies.
\end{abstract}

Keywords: Bone density; Obesity; Adolescent; Vitamin D; Body composition.

\section{RESUMO}

Introdução: A adolescência é caracterizada como uma fase de intenso desenvolvimento do sistema esquelético. A maximização do pico de massa óssea durante a adolescência contribui para a redução do risco de fraturas na vida adulta. Objetivos: Analisar a densidade mineral óssea (DMO) e sua relação com o estado nutricional e a concentração plasmática de vitamina D em adolescentes com excesso de peso. Métodos: Trata-se de uma pesquisa transversal, de caráter exploratório, onde foram analisados dados de 102 adolescentes com excesso de peso, de ambos os sexos. Avaliaram-se índice de massa corporal (IMC), circunferência abdominal (CA), consumo de micronutrientes (vitamina D, cálcio, magnésio e fósforo), concentração sérica de 25-hidroxicolecalciferol (25(OH)D), DMO do fêmur proximal, da coluna lombar (L7-L4) e do corpo total, \% gordura total (\%G), massa gorda (MG) e massa magra (MM) totais e índices de massa gorda (IMG) e massa magra (IMM). Resultados: Os adolescentes do sexo masculino ( $n=53)$ apresentaram maiores valores de peso, estatura, CA, MM e IMM e para o sexo feminino ( $n=49)$ encontrou-se maior $\%$ G. A maioria estava com obesidade (53,9\%) e DMO dentro da normalidade para todos os sítios de avaliação. Dos 84 adolescentes que realizaram a dosagem de 25(OH)D, 33,3\% apresentaram valores considerados insuficientes ou deficientes. A análise de regressão linear multivariada demonstrou que a variável mais importante como preditora independente da DMO para as meninas foi o IMM, independente do sítio de avaliação. Nos meninos, além do IMM, - IMC-Z também se comportou como variável determinante dos resultados da DMO na parte proximal do fêmur (colo e total). Conclusão: Nesta amostra de adolescentes, o IMM apresentou-se como preditor positivo para a DMO em ambos os sexos; e o IMC-Z como preditor positivo apenas para a parte proximal do fêmur no sexo masculino. Nível de evidência ll; Estudos prognósticos.

Descritores: Densidade óssea; Obesidade; Adolescente; Vitamina D; Composição corporal.

\section{RESUMEN}

Introducción: La adolescencia se caracteriza como una fase de intenso desarrollo del sistema esquelético. La maximización del pico de masa ósea durante la adolescencia contribuye para la reducción del riesgo de fracturas en la vida adulta. Objetivos: Analizar la densidad mineral ósea (DMO) y su relación con el estado nutricional y la concentración plasmática de vitamina D en adolescentes con exceso de peso. Métodos: Se trata de una investigación transversal, de carácter exploratoria, en donde se analizaron datos de 102 adolescentes con exceso de peso, de ambos sexos. Se evaluaron Indice de masa corporal (IMC), circunferencia abdominal (CA), consumo de micronutrientes (vitamina D, calcio, magnesio y fósforo), concentración sérica de 25-hidroxicolecalciferol (25(OH)D), DMO del fémur proximal, de la columna lumbar (L1-L4) y del cuerpo total, \% grasa total (\%G), masa grasa (MG) y masa magra (MM) 
totales e índices de masa grasa (IMG) y masa magra (IMM). Resultados: Los adolescentes del sexo masculino ( $n=53)$ presentaron mayores valores de peso, estatura, $C A, M M$ eIMM; y para el sexo femenino $(n=49)$ se encontró mayor \%G. La mayoría estaba con obesidad (53,9\%) y DMO dentro de la normalidad para todos los sitios de evaluación. De los 84 adolescentes que realizaron el dosaje de 25(OH)D, 33,3\% presentó valores considerados insuficientes o deficientes. El análisis de regresión lineal multivariada demostró que la variable más importante como predictora independiente de la DMO para las niñas era el IMM, independientemente del sitio de evaluación. En los niños, además del IMM, el IMC-Z también se comportó como variable determinante de los resultados de la DMO en la parte proximal del fémur (cuello y total). Conclusión: En esta muestra de adolescentes, el IMM se presentó como un predictor positivo para la DMO en ambos sexos; y el IMC-Z como predictor positivo sólo para la parte proximal del fémur en el sexo masculino.

\section{Nivel de evidencia ll; Estudios pronósticos.}

Descriptores: Densidad ósea; Obesidad; Adolescente; Vitamina D; Composición corporal.

\section{INTRODUCTION}

Adolescence is a stage of human development with specific needs and characteristics. Significant changes in the biopsychosocial order make adolescence a period of potentialities, vulnerability and risks. ${ }^{1}$ The skeletal system is one of the organic systems with intense development at this stage of the life cycle, period in which the peak bone mass occurs and the magnitude of this process contributes to reduce the risk of fractures in adulthood. ${ }^{2}$

Body weight, age and sexual maturation can be considered as the main factors related to bone mass during adolescence. ${ }^{3}$ The variation in peak bone mass is explained by numerous factors, such as gender, race, dietary habits and physical activity, hereditary factors, hormonal factors, presence of intercurrent diseases, chronic use of medications and body composition characteristics.4 Adiposity excess, although associated with increased bone size, can have an adverse effect on its quality. ${ }^{2}$ Increased body weight interferes with both bone mass acquisition and loss and is directly linked to the risk of being overweight or obese. ${ }^{4}$

Adipose and bone tissues are metabolically active organs due to the constant production and release of molecules, cytokines and hormones. These molecules modulate via endocrine and paracrine signaling a number of metabolic activities. ${ }^{2}$ The pathophysiological role of adipose tissue in bone tissue homeostasis is probably related to the action of these molecules in a homeostatic feedback system, in which adipokines and molecules secreted by osteoblasts and osteoclasts act on the bone-adipose-active axis. Deregulation of secreted factors in adipose tissue is not only linked to overweight and its complications, but also has important effects on bone metabolism. ${ }^{5}$

Obesity is a worrisome condition due to the increasing number of cases in children and adolescents, being a strong predictor of adult obesity ${ }^{6}$ and related to the presence of comorbidities in all life cycle stages. ${ }^{2}$ The prevalence of overweight and obesity among children and adolescents aged 5 to 19 increased dramatically from only 4\% in 1975 to just over 18\% in 2016. While just under 1\% of children and adolescents aged 5 to 19 were obese in 1975, more than 124 million children and adolescents (6\% of girls and $8 \%$ of boys) were obese in 2016, which requires immediate public health actions. ${ }^{6}$

When considering that: (a) obesity and osteoporosis are serious global public health issues, ${ }^{2,6}$ (b) overweight and its comorbidities are increasingly present in early stages of the life cycle, ${ }^{1,6}$ (c) the higher life expectancy led to an increased prevalence of osteoporosis and fractures $^{4}$ and (d) there is a correlation between body weight and bone mass development, 3,4 this research was conducted with the main objective of analyzing bone mass and its relationship with nutritional status and serum vitamin D concentration in overweight adolescents.

\section{MATERIAL AND METHODS}

This is a cross-sectional, descriptive, exploratory and quantitative study, based on data analysis from overweight adolescents selected from four Family Health Strategies Units (ESFs) of Blumenau/SC, linked to the Research Project "Life and health of adolescents in chronic condition," approved by the Research Ethics Committee (612.197/2014). This study included 249 adolescents registered in the research database with anthropometric information of 840 out of a total of 1,254 adolescents enrolled in the four ESF. Adolescents using continuous medication or vitamin D supplements, on a diet due to the presence of some disease, who performed scheduled physical activity in addition to curricular physical education and those who did not perform bone mass evaluation were excluded.

We measured body mass and height to determine body mass index $(\mathrm{BMI})$, which was classified according to $\mathrm{Z}$ score $(\mathrm{BMI}-\mathrm{Z}){ }_{1}^{8}$ and waist circumference (WC). Food intake was collected through the Food Frequency Questionnaire for Adolescents (FFQA). ${ }^{9}$ To estimate the intake of micronutrients (vitamin D, calcium, magnesium and phosphorus), we used the Food Composition Table as the main basis, ${ }^{10}$ relating it to the frequency of intake. For foods not found, we used data from the United States Department of Agriculture (USDA) database.

Bone mass and body composition were evaluated by double X-ray densitometry (DXA) with Hollogic ${ }^{\circledR}$ Explorer device (Bedford, Massachusetts, USA). To evaluate bone mass, we used bone mineral density (BMD) in the whole body, femoral neck, total femur and lumbar spine (L1-L4) sites. In body composition, we used the parameters: body fat percentage (\%F), fat mass (FM) and lean mass $(\mathrm{LM})$ in Kg. BMD was measured in $\mathrm{g} / \mathrm{cm}^{2}$ and later transformed into a Z-score. For interpreting BMD, we followed the criteria by Zemel et al ${ }^{11}$, who considers normal a BMD with Z-score $\geq-1$ SD; low bone mass (LM) a BMD with Z-score between 1 and -2 SD; and very low bone mass (VLM) a BMD with Z-score $\leq-2$ $\mathrm{SD}$. From the \%F data, we calculated the total fat mass (FM) and the total lean mass (LM), and then the fat mass index (FMI) (FM divided by height squared) and the lean mass index (LMI) (LM divided by height squared).

The serum concentration of 25-hydroxycholecalciferol $(25(\mathrm{OH}) \mathrm{D})$ was determined by high performance liquid chromatography, with ultraviolet reading by efficient protein precipitation and solid-phase extraction, where components are removed. Values lower than $15 \mathrm{ng} / \mathrm{ml}$ and between 15 and $20 \mathrm{ng} / \mathrm{ml}$, were classified as deficiency and insufficiency, respectively. ${ }^{12}$

The data undertook statistical analysis. Normality of the distribution of the variables was verified by the Kolmogorov-Smirnov test. For bivariate analysis with gender, we used Student's t-test or Mann-Whitney's U test; for BMD, we used Pearson correlation or Spearman's rank correlation. We performed stepwise multiple regression analyses to determine the possible effects of each independent variable over dependent variables (Lumbar spine, femoral neck, total femur and total body BMD). Significance was considered when $p<0.05$ 


\section{RESULTS}

Table 1 shows the adolescents' main characteristics, stratified by gender. The median age was 13 years and the median \%F was 36.5\%. Male adolescents had higher values of weight, height, AC, FM and LMI and female adolescents had a higher \%F mean value. Most adolescents were obese (53.9\%) or had normal BMD. Of the 84 adolescents who underwent the laboratory examination, $66.7 \%(n=58)$ had normal serum levels of $25(\mathrm{OH}) \mathrm{D}$ and $33.3 \%(\mathrm{n}=28)$, levels considered insufficient or deficient. (Table 2)

In the bivariate analysis, the linear correlation coefficients showed that, for girls, the femoral neck BMD presented a positive correlation with the BMI $\left(\mathrm{kg} / \mathrm{m}^{2}\right)$ and FMI values, and a negative correlation with the serum vitamin D. In males, there was a positive BMD correlation in all evaluation sites with height, BMI $\left(\mathrm{kg} / \mathrm{m}^{2}\right)$, LM and FM. (Table 3)

Multivariate linear regression analysis showed that the most important variable as an independent BMD predictor for girls was the LMI, for total body, total femur and femoral neck sites. We found no significant predictor variables in the lumbar spine. Unlike girls, in boys, LMI was the most important independent predictor in all sites evaluated. In addition, BMI-Z also behaved as a decisive variable in the femur BMD results (neck and total). (Table 4)

\section{DISCUSSION}

In this study, we observed the prevalence of adolescents with obesity and excess abdominal fat, with boys showing higher values of lean mass and abdominal fat markers and girls of total fat. Aspects that can be justified by the presence of sexual dimorphism, which involves genetic, hormonal and environmental factors, ${ }^{13}$ begining in adolescence, during the different pubertal stages. ${ }^{5}$ During puberty, changes occur in the adolescents' growth spurt and body composition, with the most significant BMI increase occurring between seven and 15 years. However, boys develop FM more slowly, or they present a decrease in FMI with a rapid increase in LMI between 13 and 15 years. Girls, on the other hand, present a similar increase in LMI and FMI up to 13 years of age, with a
Table 2. Percentage of adolescents according to anthropometric, biochemical and densitometric classification.

\begin{tabular}{|c|c|c|c|c|}
\hline Variable & Classification & $\begin{array}{l}\text { Total } \\
\%(n)\end{array}$ & $\begin{array}{c}\text { Female } \\
\%(n)\end{array}$ & $\begin{array}{l}\text { Male } \\
\%(n)\end{array}$ \\
\hline \multirow{4}{*}{ BMI-Z } & Eutrophy & $7.8(8)$ & $10.2(5)$ & $5.7(3)$ \\
\hline & Overweight & $38.2(39)$ & $40.8(20)$ & $35.9(19)$ \\
\hline & Obesity & $53.9(55)$ & $49.0(24)$ & $58.5(31)$ \\
\hline & Total & $100.0(102)$ & $100.0(49)$ & $100.0(53)$ \\
\hline \multirow{5}{*}{$\begin{array}{c}\text { Lumbar } \\
\text { spine BMD }\end{array}$} & Very low & $3.0(3)$ & $2.0(1)$ & $3.8(2)$ \\
\hline & Low & $10.9(11)$ & $8.2(4)$ & $13.5(7)$ \\
\hline & Normal & $78.2(79)$ & $83.7(41)$ & $73.1(38)$ \\
\hline & High & $7.9(8)$ & $6.1(3)$ & $9.6(5)$ \\
\hline & Total & $100.0(101)$ & $100.0(49)$ & $100.0(52)$ \\
\hline \multirow{5}{*}{$\begin{array}{c}\text { Total body } \\
\text { BMD }\end{array}$} & Very low & $5.9(6)$ & $4.1(2)$ & $7.7(4)$ \\
\hline & Low & $14.9(15)$ & $18.4(9)$ & $11.5(6)$ \\
\hline & Normal & $76.2(77)$ & $77.5(38)$ & $75.0(39)$ \\
\hline & High & $3.0(3)$ & $0.00(0)$ & $5.8(3)$ \\
\hline & Total & $100.0(101)$ & $100.0(49)$ & $100.0(52)$ \\
\hline \multirow{5}{*}{$\begin{array}{c}\text { Femoral } \\
\text { neck BMD }\end{array}$} & Very low & $1.0(1)$ & $0.0(0)$ & $1.9(1)$ \\
\hline & Low & $5.9(6)$ & $4.2(2)$ & $7.5(4)$ \\
\hline & Normal & $76.2(77)$ & 77.1 (37) & $75.5(40)$ \\
\hline & High & $16.8(17)$ & $18.7(9)$ & $15.1(8)$ \\
\hline & Total & $100.0(101)$ & $100.0(48)$ & $100.0(53)$ \\
\hline \multirow{5}{*}{$\begin{array}{c}\text { Total femur } \\
\text { BMD }\end{array}$} & Very low & $3.0(3)$ & $2.1(1)$ & $3.8(2)$ \\
\hline & Low & $6.9(7)$ & $10.4(5)$ & $3.8(2)$ \\
\hline & Normal & $85.1(86)$ & $87.5(42)$ & $83.0(44)$ \\
\hline & High & $5.0(5)$ & $0.0(0)$ & $9.4(5)$ \\
\hline & Total & $100.0(101)$ & $100.0(48)$ & $100.0(53)$ \\
\hline \multirow{4}{*}{$\begin{array}{c}\text { Vitamin D } \\
(25 \mathrm{OHD})\end{array}$} & Sufficient & $66.7(56)$ & $63.4(26)$ & $69.8(30)$ \\
\hline & Insufficient & $21.4(18)$ & $26.8(11)$ & $16.3(7)$ \\
\hline & Deficient & $11.9(10)$ & $9.8(4)$ & $13.9(6)$ \\
\hline & Total & $100.0(84)$ & 100.0 & 100.0 \\
\hline
\end{tabular}

Body mass index (BMI); bone mineral density (MOD); female (fem); male

Table 1. Descriptive measurements of anthropometric, densitometric, biochemical and micronutrient intake variables of overweight adolescents according to gender, Blumenau (SC), Brazil, 2014.

\begin{tabular}{|c|c|c|c|}
\hline Variable & $\begin{array}{c}\text { Total } \\
\mathrm{N}=102\end{array}$ & $\begin{array}{c}\text { Female } \\
\mathrm{N}=49\end{array}$ & $\begin{array}{l}\text { Male } \\
\mathrm{N}=53\end{array}$ \\
\hline Age (years) & $13(10-19)$ & $13(10-17)$ & $14(10-19)$ \\
\hline Age (months) & $166.6 \pm 27.7$ & $161.7 \pm 25.4$ & $171.1 \pm 29.2$ \\
\hline Weight $(\mathrm{kg})^{*}$ & $72.5 \pm 17.0$ & $66.3 \pm 14.1$ & $78.3 \pm 17.5$ \\
\hline Height $(m)^{*}$ & $1.6 \pm 0.1$ & $1.6 \pm 0.1$ & $1.7 \pm 0.1$ \\
\hline Body mass index $\left(\mathrm{kg} / \mathrm{m}^{2}\right)$ & $26.7(20.3-40.6)$ & $26.0(20.3-35.6)$ & $27.0(20.3-40.6)$ \\
\hline Body mass index (Z-score) & $1.6 \pm 0.6$ & $1.5 \pm 0.5$ & $1.7 \pm 0.6$ \\
\hline Waist circumference $(\mathrm{cm})^{*}$ & $94.6 \pm 11.8$ & $91.1 \pm 11.6$ & $98.0 \pm 11.1$ \\
\hline$\%$ total fat* & $36.5(13.3-49.3)$ & $39.3(26.2-45.5)$ & $32.7(13.3-49.3)$ \\
\hline Lean mass $(\mathrm{kg})$ & $25.1 \pm 9.1$ & $25.2 \pm 8.3$ & $25.1 \pm 9.9$ \\
\hline Fat mass $(\mathrm{kg})^{*}$ & $47.4 \pm 12.3$ & $41.1 \pm 9.2$ & $53.2 \pm 12.1$ \\
\hline Lean mass index $\left(\mathrm{kg} / \mathrm{m}^{2}\right)^{*}$ & $17.7 \pm 2.9$ & $16.5 \pm 2.8$ & $18.8 \pm 2.6$ \\
\hline Fat mass index $\left(\mathrm{kg} / \mathrm{m}^{2}\right)$ & $9.5 \pm 3.3$ & $10.1 \pm 2.9$ & $9.0 \pm 3.6$ \\
\hline Lumbar spine (Z-score) $)^{* *}$ & $0.254 \pm 1.169$ & $0.296 \pm 1.049$ & $0.215 \pm 1.281$ \\
\hline Femoral neck (Z-score) ${ }^{* *}$ & $0.717 \pm 1.233$ & $0.769 \pm 1.164$ & $0.670 \pm 1.301$ \\
\hline Total body $\left(Z\right.$-score) ${ }^{* *}$ & $-0.130 \pm 1.154$ & $-0.140 \pm 1.040$ & $-0.120 \pm 1.261$ \\
\hline Total femur (Z-score) $)^{* *}$ & $0.338 \pm 1.120$ & $0.312 \pm 1.111$ & $0.360 \pm 1.138$ \\
\hline 25-Hydroxycholecalciferol (ng/mL) & $25.3(11.5-50.1)$ & $22.8(13.7-45.7)$ & $25.5(11.5-50.1)$ \\
\hline Calcium $(\mathrm{mg})$ & $649.4(76.8-1771.7)$ & $642.3(78.6-1771.7)$ & $666.1(76.8-1443.8)$ \\
\hline Phosphorus (mg) & $957.2(115.0-2815.1)$ & $985.4(115.0-2438.6)$ & $955.3(212.0-2815.1)$ \\
\hline Magnesium (mg) & $245.2(31.7-663.1)$ & $271.1(31.7-625.6)$ & $231.7(48.3-663.1)$ \\
\hline Vitamin D (mcg) & $219.0(0.4-679.0)$ & $219.1(0.4-674.1)$ & $221.5(0.6-679.0)$ \\
\hline
\end{tabular}




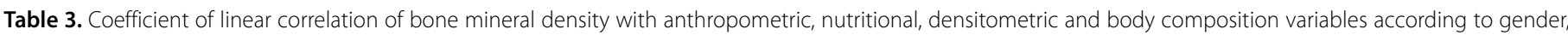
Blumenau (SC), Brazil, 2014

\begin{tabular}{|c|c|c|c|c|c|c|c|c|}
\hline \multirow[t]{2}{*}{ Variable } & \multicolumn{2}{|c|}{ Lumbar spine BMD } & \multicolumn{2}{|c|}{ Total body BMD } & \multicolumn{2}{|c|}{ Femoral neck BMD } & \multicolumn{2}{|c|}{ BMD total femur } \\
\hline & fem & male & fem & male & fem & male & fem & male \\
\hline Age (years) & -0.076 & -0.105 & -0.108 & -0.064 & -0.020 & -0.190 & -0.060 & -0.196 \\
\hline Age (months) & 0.051 & $0.379^{* *}$ & 0.162 & $0.399^{* *}$ & 0.204 & $0.389^{* *}$ & 0.072 & $0.338^{*}$ \\
\hline Weight (kg) & -0.013 & 0.214 & -0.008 & 0.229 & -0.017 & 0.124 & -0.061 & 0.101 \\
\hline Height $(\mathrm{m})$ & 0.118 & $0.355^{* *}$ & 0.198 & $0.304^{* *}$ & $0.352^{*}$ & $0.419^{* *}$ & 0.181 & $0.362^{* *}$ \\
\hline Body mass index $\left(\mathrm{kg} / \mathrm{m}^{2}\right)^{\#}$ & 0.166 & $0.365^{* *}$ & 0.269 & $0.336^{*}$ & $0.321^{*}$ & $0.453^{* *}$ & 0.198 & $0.435^{* *}$ \\
\hline Body mass index (Z-score) & -0.072 & 0.219 & 0.045 & 0.164 & 0.173 & 0.222 & 0.046 & 0.178 \\
\hline Waist circumference $(\mathrm{cm})^{*}$ & -0.105 & -0.042 & -0.083 & -0.128 & 0.169 & 0.048 & -0.026 & -0.008 \\
\hline$\%$ total fat ${ }^{\#}$ & -0.046 & 0.208 & 0.046 & 0.179 & 0.177 & 0.257 & 0.014 & 0.211 \\
\hline Lean mass $(\mathrm{kg})$ & 0.120 & $0.399 * *$ & 0.207 & $0.452^{* *}$ & 0.153 & $0.351^{* *}$ & 0.124 & $0.315^{*}$ \\
\hline Fat mass (kg) & 0.187 & $0.499 * *$ & 0.277 & $0.551^{* *}$ & 0.237 & $0.490^{* *}$ & 0.275 & $0.456^{* *}$ \\
\hline Lean mass index $\left(\mathrm{kg} / \mathrm{m}^{2}\right)^{*}$ & -0.025 & 0.172 & 0.051 & 0.128 & 0.232 & 0.242 & 0.067 & 0.206 \\
\hline Fat mass index $\left(\mathrm{kg} / \mathrm{m}^{2}\right)$ & -0.188 & -0.083 & -0.150 & 0.055 & $-0.331^{*}$ & -0.018 & -0.217 & -0.028 \\
\hline Lumbar spine (Z-score) $)^{* *}$ & -0.053 & -0.010 & 0.107 & 0.090 & -0.031 & 0.150 & 0.000 & 0.035 \\
\hline Femoral neck (Z-score) ${ }^{* *}$ & -0.062 & -0.018 & 0.121 & 0.044 & -0.029 & 0.151 & -0.010 & 0.062 \\
\hline Total body (Z-score) $)^{* *}$ & 0.059 & -0.023 & 0.227 & 0.018 & 0.117 & 0.085 & 0.095 & 0.008 \\
\hline Total femur (Z-score) $)^{* *}$ & 0.059 & 0.013 & 0.183 & 0.034 & 0.110 & -0.164 & 0.080 & -0.149 \\
\hline $25(\mathrm{OH}) \mathrm{D}(\mathrm{ng} / \mathrm{mL}) \#$ & -0.188 & -0.083 & -0.150 & 0.055 & $-0.331^{*}$ & -0.018 & -0.217 & -0.028 \\
\hline Calcium (mg) \# & -0.053 & -0.010 & 0.107 & 0.090 & -0.031 & 0.150 & 0.000 & 0.035 \\
\hline Phosphorus (mg) \# & -0.062 & -0.018 & 0.121 & 0.044 & -0.029 & 0.151 & -0.010 & 0.062 \\
\hline Magnesium (mg) \# & 0.059 & -0.023 & 0.227 & 0.018 & 0.117 & 0.085 & 0.095 & 0.008 \\
\hline Vitamin D (mcg) \# & 0.059 & 0.013 & 0.183 & 0.034 & 0.110 & -0.164 & 0.080 & -0.149 \\
\hline
\end{tabular}

Bone mineral density (BMD);25-hydroxycholecalciferol (25(OH)D); $\left(^{*}\right)$ Spermann's correlation; other variables: Pearson correlation; $\left(^{*}\right) p<0.05 ;\left(^{* *}\right) p<0.01$

Table 4. BMD multivariate linear regression analysis regarding gender, Blumenau (SC), Brazil, 2014.

\begin{tabular}{c|c|c|c|c|c}
\hline \multirow{2}{*}{ Gender } & BMD & Model & $\mathbf{R}^{\mathbf{2}}$ & $\begin{array}{c}\text { Adjusted } \\
\mathbf{R}^{\mathbf{2}}\end{array}$ & $\mathbf{p}$ \\
\hline \multirow{4}{*}{ Female } & Lumbar spine & $\begin{array}{c}\text { There were no } \\
\text { significant variables }\end{array}$ & & & \\
\cline { 2 - 6 } & Total body & $-1.853+(0.104 \times \mathrm{LMI})$ & 0.077 & 0.057 & 0.050 \\
\cline { 2 - 6 } & Femoral neck & $-1.708+(0.093 \times \mathrm{LMI})$ & 0.109 & 0.090 & 0.022 \\
\cline { 2 - 6 } & Total femur & $-2.314+(0.162 \times \mathrm{LMI})$ & 0.076 & 0.055 & 0.050 \\
\hline \multirow{5}{*}{ Male } & Lumbar spine & $-4.621+(0.259 \times \mathrm{LMI})$ & 0.249 & 0.234 & $<0.001$ \\
\cline { 2 - 6 } & Total body & $-5.381+(0.282 \times \mathrm{LMI})$ & 0.304 & 0.290 & $<0.001$ \\
\cline { 2 - 6 } & Femoral neck & $\begin{array}{c}-3.921+(0.184 \times \mathrm{LMI}) \\
+(0.677 \times \mathrm{BMI}-\mathrm{Z})\end{array}$ & 0.317 & 0.289 & 0.022 \\
\cline { 2 - 6 } & Total femur & $\begin{array}{c}-3.371+(0.147 \times \mathrm{LMI}) \\
+(0.584 \times \mathrm{BMI}-\mathrm{Z})\end{array}$ & 0.282 & 0.253 & 0.028 \\
\hline
\end{tabular}

Bone mineral density (BMD); Lean Mass index (LMI); Body Mass Index (BMI).

subsequent significant and continuous increase in FM. ${ }^{14}$ Although we did not evaluate the pubertal stage, it is worth highlighting that in our sample most adolescents were older than 13 years, age compatible with the pubertal development.

BMD evaluation showed normal bone mass in most adolescents studied, regardless of the anatomical site evaluated and similar in both genders. In addition, we found no correlation between BMD and the indicators of total adiposity. Similar results are described in obese adolescents of both genders. ${ }^{3,15}$

The data available in the literature regarding the relationship between fat mass markers and BMD are conflicting. Some studies describe both $\mathrm{FMI}^{5}$ and $\mathrm{FM}^{16}$ as bone mass predictors in female adolescents (regardless of nutritional status). While others have shown that the accumulation of body fat is unfavorable to bone structure in males, ${ }^{17}$ females ${ }^{18}$ or in both genders. ${ }^{19}$

Although the association between obesity and increased bone mass is explained by biomechanical, ${ }^{20}$ hormonal ${ }^{6}$ and cell differentiation ${ }^{21}$ mechanisms, it seems that a higher BMD observed in individuals classified as obese would be disproportional to body weight increase. In this case, adiposity is the largest component derived from overweight. ${ }^{21}$ There is also evidence that the BMD per BMI unit is lower in obesity, 22 and of the negative impact exerted by excess body fat on bone quality in adults and children. ${ }^{23}$ An adequate amount of body fat is, then, needed for bone mass development, but its excess would be harmful. ${ }^{24}$ Therefore, obesity could not be considered a protective factor against osteoporosis. ${ }^{16}$

Increased daily calcium and protein intake and prevention of vitamin D insufficiency have a potential impact on improving and maintaining bone health and protecting against fractures at all stages of life. ${ }^{20,2} \mathrm{Ho}$ wever, in the adolescents evaluated here, we found no BMD correlations with micronutrient intake; results that are in line with other studies, 3,25 and with the serum concentration of vitamin D. It should be noted that persistent vitamin D inadequacy during the entire adolescence stage can prevent the ideal peak of bone mass set for adulthood. ${ }^{26}$ Vitamin $D$ is an essential nutrient, which plays an important role in calcium homeostasis and bone health. ${ }^{27}$ The cross-sectional design of our study may have hindered verifying the relationship of vitamin $D$ and micronutrient intake with BMD.

In the multiple regression analysis, LMI was a positive mineralization predictor for both genders. Similar results have shown that LM is the body component that most influences acquiring or maintaining bone mass, both in adolescence ${ }^{16,20}$ and in other stages of life..$^{28}$ It is justified by the mechanical stress stimulus originated from the greater amount of LM in obese individuals. ${ }^{20}$ LM positively influences bone mass during osteogenesis, in addition to reducing or avoiding bone loss during a period of caloric restriction with weight loss, especially when associated with adequate calcium intake. ${ }^{21}$ A static load proportional to the amount of adipose tissue seems to cause less bone expansion than the dynamic load, proportional to the amount of LM. ${ }^{24}$ We also found that, particularly in males, the BMI-Z values influenced BMD positively and to a greater extent than the LMI, in the anatomical sites of the lower limbs. The femur is exposed to greater mechanical stress generated by body weight, 29 which favors the BMD increase, to benefit the body's support, because the bone adapts to the mechanical loads applied to it. ${ }^{6}$ Moreover, this generated load stimulates bone formation, both by reducing apoptosis, 
as well as by increasing proliferation and differentiation of osteoblasts and osteocytes, which favor osteoclastogenesis. ${ }^{21}$

The speed of growth in length and femoral strength is highly correlated with the speed of increased body weight, very little correlated with growth in stature, but significantly with the size of the thigh muscle. ${ }^{30}$ This shows that the LM is a strong predictor of BMD of the proximal femur in all age groups. ${ }^{16}$ These correlations are more significant in males due to the greater LM amount and, consequently, a higher body weight, which could justify the high correlation found for femoral (neck and total) BMD with LMI and BMI-Z in boys and only the influence of LMI on the spine and total body, due to the lower static stimulus in these regions.

Thus, a very low body weight, especially with lower $L M$, would be harmful to the bones, ${ }^{28}$ and normal levels of body fat would support bone health in the development of children and adolescents. ${ }^{24}$ The higher the body weight, the higher the BMI and, consequently, the relationship of BMD with the lower limbs. However, body weight includes fat and LM, the latter being the positive influence on bone mass.

Studies have identified bone mass loss with weight loss programs for obese individuals. This loss may vary according to age (worse with advancing age), gender and the individual's adiposity (proportional to the amount of fat stored and weight loss). ${ }^{25,21}$ When undergoing caloric restriction, obese individuals tend to have greater bone loss due to greater decline in estrogen levels and other sex steroids. ${ }^{21}$ However, weight loss accompanied by physical activity (mainly impact exercises) is associated with lower bone loss when compared with weight loss followed solely by caloric restriction. ${ }^{15,2}$ Corroborating these observations, studies cite that obesity does not provide mechanical advantage for the bone if not accompanied by greater lean mass, resulting from an physically active lifestyle and adequate nutrition. ${ }^{21}$

The results of this study show the influence of body composition on BMD in overweight adolescents, especially LM. In this sense, stimulating regular physical activity in this health condition assumes special importance, not only for promoting weight loss but also for acquiring a body composition that favors peak bone mass.

\section{CONCLUSIONS}

The results of this study show that body composition is a BMD predictor in overweight adolescents. LM was a positive BMD predictor in both genders at total body, femoral neck and total femur sites.

In males, in addition to body composition, age-adjusted BMI (BMI-Z) proved to be a positive BMD predictor in the proximal femur.

There was no association between BMD and adiposity parameters, micronutrient intake (calcium, phosphorus, magnesium and vitamin D) and serum vitamin D levels.

\section{ACKNOWLEDGMENTS}

We thank the adolescents participating in the research, as well as their guardians, the PROPET-Saúde team and the ESFs participating in the project, which allowed and assisted the study.

All authors declare no potential conflict of interest related to this article

AUTHORS' CONTRIBUTIONS: Each author made significant individual contributions to this manuscript. SKL: study design, data collection, writing and final revision of the manuscript; NRSL: study design, data collection, writing, and final revision of the manuscript. CAS: statistical analysis, intellectual concept and final revision. DMV: study design, intellectual concept and final revision. LCAC: study design, intellectual concept, statistical analysis and final revision.

\section{REFERENCES}

1. Ruiz LD, Zuelch ML, Dimitratos SM, Scherr RE. Adolescent Obesity: Diet Quality, Psychosocial Health, and Cardiometabolic Risk Factors. Nutrients. 2019;12(1):43.

2. Fintini D, Cianfarani S, Cofini M, Andreoletti A, Ubertini GM, Cappa M, et al. The Bones of Children With Obesity. Front Endocrinol (Lausanne). 2020;11:1-16.

3. Fonseca RMC, Oliveira RJ, Pereira RW, França NM. Densidade mineral óssea associada a características físicas e estilo de vida em adolescentes. Rev Bras Med Esporte. 2012;18(6):381-4.

4. Mosca LN, Silva VN, Goldberg TBL. A influência do excesso de gordura corporal sobre a massa óssea de adolescentes. In: Jesus NF, Soares Junior JM, Moraes SDTA. Adolescência e Saúde: construindo saberes, unindo forças, consolidando direitos. São Paulo: Instituto de Saúde; 2018.

5. Kotnik P, Posovszky PF, Wabitsch M. Endocrine and metabolic effects of adipose tissue in children and adolescentes. Zdrav Var. 2015;54(2):131-8.

6. World Health Organization. Obesity and overweight. 2020 [Acesso em 2014 jun 26]. Disponível em: https://www.who.int/news-room/fact-sheets/detail/obesity-and-overweight

7. World Health Organization. Childhood overweight and obesity [Acesso em 2014 Sept 07]. Disponivel em http://www.who.int/dietphysicalactivity/childhood/en/

8. Onis M, Onyango AW, Borghi E, Siyam A, Nishida C, Siekmann J. Development of a WHO growth reference for school-aged children and adolescents. Bull World Health Organ. 2007;85(9):660-7.

9. Voci SM, Enes CC, Slater B. Validação do Questionário de Freqüência Alimentar para Adolescentes (QFAA) por grupos de alimentos em uma população de escolares. Rev Bras Epidemiol. 2008;11(4):561-72.

10. Philippi ST. Tabela de composição de alimentos: suporte para decisão nutricional. 2. ed. Brasília: Coronário; 2002.

11.Zemel BS, Petit M. Evaluation. In: Sawyer AJ, Bachrach LK, Fung EB, editors. Bone Densitometry in Growing Patients: Guidelines for Clinical Practice. Totowa, New Jesrsey: Humana Press; 2007.p. 11525

12. Misra M, Pacaud D, Petryk A, Collett-Solberg PF, Kappy M. Vitamin D deficiency in children and its management: review of current knowledge and recommendations. Pediatrics. 2008;122(2):398-417.

13. Taylor RW, Grant AM, Williams SM, Goulding A. Sex Differences in Regional Body Fat Distribution From Pre-to Postpuberty. Obesity (Silver Spring). 2010;18(7):1410-6

14. Ma J, Feng N, Zhang S, Pan Y, Huang Y. Comparison of changes in body composition during puberty development of obese and normal-weight children in China. Biomed Environ Sci. 2009;22(5):413-8.

15. Santos LC, Cintra IP, Fisberg M, Castro ML, Martini LA. Associação entre a perda de peso, a massa óssea, a composição corporal e o consumo alimentar de adolescentes obesos pós-púberes. Arq Bras Endocrino Metab. 2008;52(6):1001-8.

16. Gjesdal CG, Halse Jl, Eide GE, Brun JG, Tell GS. Impact of lean mass and fat mass on bone mineral density: the Hordaland Health Study. Maturitas. 2008;59(2):191-200.

17. Goulding A, Jones IE, Taylor RW, Wiliams SM, Manning PJ. Bone mineral density and body composition in boys with distal forearm fractures: a dual-energy x-ray absorptiometry study. J Pediatr. 2001;139(4):509-15.

18. Weiler HA, Janzen L, Green K, Grabowski J, Seshia MM, Yuen KC. Percent body fat and bone mass in healthy Canadian females 10 to 19 years of age. Bone. 2000;27(2):203-7.

19. Janicka A, Wren TAL, Sanchez MM, Dorey F, Kim PS, Mittelman SD, et al. Fat mass is not beneficial to bone in adolescents and young adults. J Clin Endocrinol Metab. 2007;92(1):143-7.

20. Leonard MB, Schults J, Wilson BA, Tershakovec AM, Zemel BS. Obesity during childhood and adolescence augments bone mass and bone dimensions. Am J Clin Nutr. 2004;80(2):514-23.

21. Shapses AS, Sukumar D. Bone metabolism in obesity and weight loss. Annu Rev Nutr. 2012;32:287-309.

22. De Laet C, Kanis JA, Odén A, Johanson H, Johnell O, Delmas P. Body mass index as a predictor of fracture risk: a meta-analysis. Osteoporos Int. 2005;16(11):1330-8.

23. Sukumar D, Schlussel Y, Riedt CS, Gordon C, Stahl T, Shapses SA. Obesity alters cortical and trabecular bone density and geometry in women. Osteoporos Int. 2011;22(2):635-45.

24. Viljakainen HT, Pekkinen M, Saarnio E, Karp H, Lamberg-Allardt C, Mäkitie O. Dual effect of adipose tissue on bone health during growth. Bone. 2011;48(2):212-7.

25. Redman LM, Rood J, Anton SD, Champagne C, Smith SR, Ravussin E. Calorie restriction and bone health in young, overweight individuals. Arch Intern Med. 2008;168(17):1859-66.

26. Holick MF. Vitamin D inadequacy and implications for health. Mayo Clinic Proceedings. 2006;81(3):353-73.

27. Misra M, Motil KJ, Drezner MK, Hoppin AG. Vitamin D insufficiency and deficiency in children and adolescents. Uptodate 2014 [acesso em 2014 out]. Disponível em http://www.uptodate.com/contents/ vitamin-d-insufficiency-and-deficiency-in-children-and-adolescents.

28. Wang MC, Bachrach LK, Loan MV, Hudes M, Flegal KM, Crawford PB. The relative contributions of lean tissue mass and fat mass to bone density in young women. Bone. 2005;37(4):474-81

29. Silva CC, Goldberg TBL, Teixeira AS, Dalmas JC. Análise preditiva da densidade mineral óssea em adolescentes brasileiros eutróficos do gênero masculino. Arq Bras Endocrinol Metab. 2006:50(1):105-13

30. Ruff $C$. Growth in bone strength, body size, and muscle size in a juvenile longitudinal sample. Bone. 2003:33(3):317-29 